\title{
Hubungan Stunting dengan Prestasi Belajar Anak Sekolah Dasar di Kecamatan Tikala Manado
}

\author{
${ }^{1}$ Gregorius Gunawan \\ 2 Jeanette I. Ch. Mannopo \\ ${ }^{2}$ Rocky Wilar
}

\author{
${ }^{1}$ Program Studi Pendidikan Dokter Fakultas Kedokteran Universitas Sam Ratulangi Manado \\ ${ }^{2}$ Bagian Ilmu Kesehatan Anak Fakultas Kedokteran Unsrat \\ Email: gunawangrego@gmail.com
}

\begin{abstract}
Stunting is a condition where height is not in accordance with age. It is due to chronic malnutrition which causes nonoptimal brain development that can affect children's cognitive development, performance at school, and learning ability, as well as consequently influences learning achievement at school. This study was aimed to identify the correlation between stunting and learning achievement of elementary school students at Tikala Manado. This was an analytical study with a cross sectional design. Respondents were elementary school students at Tikala Manado aged 7-13 years that had their average grades. Data were analyzed by using unpaired T-test. The results showed that there were 232 students as respondents. Stunting was found in 103 students (44\%) and not stunting in 129 students $(56 \%)$. The average grade of stunting students was 67.16 and of not stunting students was 68.53. Statistical analysis showed that there was no significant difference between the average student grade in stunting students and not stunting students $(P=0.215 ; \alpha=0.05)$. Conclusion: There was no significant correlation between stunting and learning achievement
\end{abstract}

Keywords: stunting, learning achievement

\begin{abstract}
Abstrak: Stunting merupakan keadaan dimana tinggi badan tidak sesusai dengan usia. Hal ini dapat menyebabkan perkembangan otak tidak optimal sehingga berpengaruh pada perkembangan kognitif dan performance anak di sekolah, serta kemampuan belajar, yang selanjutnya berpengaruh pada prestasi belajar anak di sekolah. Penelitian ini bertujuan untuk mengetahui hubungan stunting dan prestasi belajar pada siswa Sekolah Dasar di Kecamatan Tikala Manado. Jenis penelitian ialah analitik dengan desain potong lintang. Responden ialah siswa sekolah dasar di Kecamatan Tikala Manado yang berusia 7-13 tahun dan rerata nilai rapor siswa. Analisis uji statistik yang digunakan ialah uji T-test tidak berpasangan. Hasil penelitian mendapatkan 232 siswa sebagai responden. Stunting didapatkan pada 103 siswa (44\%) dan yang tidak stunting 129 siswa (56\%). Rerata nilai rapor pada siswa stunting 67,16 dan yang tidak stunting 68,53. Hasil uji analisis menunjukkan tidak terdapat perbedaan rerata prestasi belajar antara siswa stunting dan tidak stunting $(P=0,215 ; \alpha=0,05)$. Simpulan: Tidak terdapat hubungan bermakna antara stunting dan prestasi belajar.
\end{abstract}

Kata kunci: stunting, prestasi belajar

Stunting didefenisikan sebagai indeks tinggi badan menurut umur (TB/U) kurang dari minus dua standar deviasi (-2 SD) dari kurva pertumbuhan WHO. ${ }^{1}$

Stunting (tinggi badan rendah menurut umur) diakui sebagai indikator terbaik untuk pertumbuhan anak yang menunjukkan gangguan gizi kronis. Anak yang stunting memiliki kemampuan belajar yang kurang dan prestasi sekolah yang buruk, bisa tidak naik kelas atau putus sekolah. ${ }^{1}$

Menurut WHO, perkiraan prevalensi 
stunting pada anak usia sekolah yang berusia 5-18 tahun di Afrika pada tahun 2015 ialah $37 \%$ dibandingkan dengan tingkat prevalensi tertinggi berikutnya $23 \%$ di Asia. ${ }^{2}$

Hasil Riset Kesehatan Dasar (Riskesdas) mengenai prevalensi anak stunting usia 5-18 tahun di Indonesia tahun 2013 mendapatkan bahwa pada anak lakilaki, prevalensi pendek tertinggi di umur 13 tahun $(40,2 \%)$, sedangkan pada anak perempuan di umur 11 tahun $(35,8 \%)$. Secara nasional prevalensi pendek pada anak umur 5-12 tahun ialah 30,7\% (12,3\% sangat pendek dan $18,4 \%$ pendek). Prevalensi sangat pendek terendah di DI Yogyakarta ialah 14,9\%) dan tertinggi di Papua sebesar 34,5\%. Sebanyak 15 provinsi dengan prevalensi sangat pendek di atas prevalensi nasional yaitu Kalimantan Tengah, Aceh, Sumatera Selatan, Jambi, Nusa Tenggara Barat, Gorontalo, Bengkulu, Maluku, Sulawesi Barat, Sumatera Utara, Kalimantan Barat, Nusa Tenggara Timur, Lampung, dan Papua. ${ }^{3}$ Prevalensi stunting di Provinsi Sulawesi Utara lebih rendah dari angka nasional $(38 \%)$ tetapi masih tergolong tinggi $31,2 \%$. Prevalensi tertinggi di Kabupaten Minahasa (39,3\%), dan terendah di perkotaan Bitung $(25,1 \%){ }^{4}$

Stunting menggambarkan keadaan kurang gizi yang kronis dimana pasokan nutrisi yang diperlukan tubuh termasuk otak berkurang. Hal ini menyebabkan perkembangan otak tidak optimal, sehingga dapat berpengaruh pada perkembangan kognitif anak, performance di sekolah, dan kemampuan belajarnya, yang akibatnya berpengaruh pada prestasi belajar anak di sekolah. ${ }^{5}$

Prestasi belajar adalah penilaian hasil usaha kegiatan belajar yang dinyatakan dalam bentuk simbol, angka, huruf, maupun kalimat yang dapat mencerminkan hasil yang sudah dicapai oleh setiap anak dalam periode tertentu. Prestasi belajar merupakan hal yang tidak dapat dipisahkan dari kegiatan belajar, karena kegiatan belajar merupakan proses, sedangkan prestasi merupakan hasil dari proses belajar.
Prestasi belajar anak sekolah dapat diketahui setelah diadakannya evaluasi. Hasil evaluasi dapat memperlihatkan tinggi atau rendahnya prestasi belajar siswa. ${ }^{6}$

Telah dilakukan beberapa penelitian hubungan antara stunting dengan prestasi belajar anak di Indonesia. ${ }^{7-9}$ Penelitian ini bertujuan untuk mengetahui hubungan stunting dengan prestasi belajar anak SD di Manado.

\section{METODE PENELITIAN}

Jenis penelitian ini ialah survei analitik observasional dengan desain potong lintang. Teknik pengambilan sampel menggunakan metode konsekutif sampling. Responden yang digunakan ialah siswa berusia 7-13 tahun dan mempunyai nilai rapor yang lengkap.

Stunting dalam penelitian ini ditentukan dengan mengukur timggi badan (TB) menggunakan microtoise, lalu di plot ke kurva CDC-2000 untuk melihat TB sesuai umur, kemudian menggunakan kriteria Waterlow $(<95 \%)$ untuk menentukan apakah stunting atau tidak stunting dengan perhitungan TB/U×100 \%. Prestasi belajar ditentukan dengan cara melihat nilai rerata hasil ujian tengah semester dari sembilan mata pelajaran yang diujiankan.

\section{HASIL PENELITIAN}

Penelitian ini dilakukan pada anak SDN di Kecamatan Tikala Manado. Pengambilan data dilakukan pada bulan Oktober hingga November 2018. Dari hasil penelitian yang dilakukan, sebanyak 74 responden tidak memberikan hasil rapor sehingga tidak memenuhi kriteria inklusi dan tersisa 232 responden yang memenuhi kriteria inklusi.

Penelitian ini dilakukan di 5 SDN di Kecamatan Tikala Manado. Terdapat 29 anak dari SDN 31, 34 anak dari SDSN 54, 67 anak dari SDN 55, 66 anak dari SDN 91 dan 36 anak dari SDN 105 (Tabel 1).

Dalam penelitian ini didapatkan 117 anak dengan jenis kelamin laki-laki (50\%) dan 115 anak dengan jenis kelamin perempuan $(50 \%)$ (Tabel 2). 
Tabel 1. Responden berdasarkan sekolah

\begin{tabular}{ccc}
\hline Sekolah & n & \% \\
\hline SDN 31 & 29 & 13 \\
SDN 54 & 34 & 15 \\
SDN 55 & 67 & 29 \\
SDN 91 & 66 & 28 \\
SDN 105 & 36 & 15 \\
Total & 232 & 100 \\
\hline
\end{tabular}

Distribusi responden menurut usia didapatkan usia 7 tahun terdapat 20 anak (9\%), usia 8 tahun terdapat 62 anak (27\%), usia 9 tahun terdapat 50 anak $(22 \%)$, usia 10 tahun terdapat 61 anak $(26 \%)$, usia 11 tahun terdapat 31 anak $(13 \%)$, usia 12 tahun terdapat 5 anak (2\%) dan usia 13 tahun terdapat 3 anak (1\%). Usia terbanyak dari responden yaitu usia 8 tahun $(27 \%)$ (Tabel 2)

Tabel 2. Karateristik responden

\begin{tabular}{lcc}
\hline $\begin{array}{c}\text { Karateristik } \\
\text { responden }\end{array}$ & n & \% \\
\hline Jenis kelamin & & \\
Laki-laki & 117 & 50 \\
Perempuan & 115 & 50 \\
Umur & & \\
7 tahun & 20 & 9 \\
8 tahun & 62 & 27 \\
9 tahun & 50 & 22 \\
10 tahun & 61 & 26 \\
11 tahun & 31 & 13 \\
12 tahun & 5 & 2 \\
13 tahun & 3 & 1 \\
Total & 232 & 100 \\
\hline
\end{tabular}

Responden terbanyak terdapat pada kelas 3 SD (36\%), dan yang paling sedikit terdapat pada kelas 6 SD (8\%) (Tabel 3).

Tabel 3. Kelas responden

\begin{tabular}{ccc}
\hline Sekolah & n & \% \\
\hline Kelas 3 & 83 & 36 \\
Kelas 4 & 50 & 22 \\
Kelas 5 & 80 & 34 \\
Kelas 6 & 19 & 8 \\
Total & 232 & 100
\end{tabular}

Dari 232 responden terdapat 103 anak stunting (44\%) dan 129 anak tidak stunting (56\%). Ke 129 anak yang tidak stunting merupakan kontrol dalam penelitian ini (Tabel 4).

Tabel 4. Jumlah reesponden anak stunting dan tidak stunting

\begin{tabular}{ccc}
\hline & n & \% \\
\hline Stunting & 103 & 44 \\
Tidak stunting & 129 & 56 \\
Total & 232 & 100 \\
\hline
\end{tabular}

Tabel tabulasi silang di bawah ini memperlihatkan 50 dari 103 anak yang stunting berjenis kelamin laki-laki dan 53 dari 103 anak yang stunting berjenis kelamin perempuan. Juga terdapat 67 dari 129 anak yang tidak stunting berjenis kelamin laki-laki dan 62 dari 129 anak berjenis kelamin perempuan (Tabel 5).

Tabel 5. Tabulasi silang jenis kelamin-umur dan stunting

\begin{tabular}{|c|c|c|c|}
\hline $\begin{array}{c}\text { Jenis } \\
\text { kelamin }\end{array}$ & $\begin{array}{c}\text { Stunting } \\
\mathbf{n}(\%)\end{array}$ & $\begin{array}{c}\text { Tidak } \\
\text { stunting } \\
\text { n }(\%)\end{array}$ & $\begin{array}{l}\text { Total } \\
\text { n }(\%)\end{array}$ \\
\hline Laki-laki & $\begin{array}{c}50 \\
(21,6 \%)\end{array}$ & $\begin{array}{c}67 \\
(28,9 \%)\end{array}$ & $\begin{array}{c}117 \\
(50,4 \%)\end{array}$ \\
\hline Perempuan & $\begin{array}{c}53 \\
(22,8 \%)\end{array}$ & $\begin{array}{c}62 \\
(26,7 \%)\end{array}$ & $\begin{array}{c}115 \\
(49,6 \%)\end{array}$ \\
\hline Total & $\begin{array}{c}103 \\
(44.4 \%)\end{array}$ & $\begin{array}{c}129 \\
(55,6 \%)\end{array}$ & $\begin{array}{c}232 \\
(100 \%)\end{array}$ \\
\hline Usia & $\begin{array}{c}\text { Stunting } \\
\mathbf{n}(\%)\end{array}$ & $\begin{array}{c}\text { Tidak } \\
\text { Stunting } \\
\text { n }(\%)\end{array}$ & $\begin{array}{l}\text { Total } \\
\text { n }(\%)\end{array}$ \\
\hline 7 Tahun & $\begin{array}{c}1 \\
(0,4 \%)\end{array}$ & $19(8,2 \%)$ & $\begin{array}{c}20 \\
(8,6 \%)\end{array}$ \\
\hline 8 Tahun & $\begin{array}{c}28 \\
(12,1 \%)\end{array}$ & $\begin{array}{c}34 \\
(14,7 \%)\end{array}$ & $\begin{array}{c}62 \\
(26,7 \%)\end{array}$ \\
\hline 9 Tahun & $23(9,9 \%)$ & $\begin{array}{c}27 \\
(11,6 \%)\end{array}$ & $\begin{array}{c}50 \\
(21,6 \%)\end{array}$ \\
\hline 10 Tahun & $\begin{array}{c}29 \\
(12,5 \%)\end{array}$ & $32(13,8)$ & $\begin{array}{c}61 \\
(26,3 \%)\end{array}$ \\
\hline 11 Tahun & $19(8,2 \%)$ & $12(5,2 \%)$ & $\begin{array}{c}31 \\
(13,4 \%)\end{array}$ \\
\hline 12 Tahun & $\begin{array}{c}2 \\
(0,9 \%)\end{array}$ & $\begin{array}{c}3 \\
(1,3 \%)\end{array}$ & $5(2,2 \%)$ \\
\hline 13 Tahun & $\begin{array}{c}1 \\
(0,4 \%)\end{array}$ & $\begin{array}{c}2 \\
(0,9 \%)\end{array}$ & $\begin{array}{c}3 \\
(1,3 \%)\end{array}$ \\
\hline Total & $\begin{array}{c}103 \\
(44,4 \%)\end{array}$ & $\begin{array}{c}129 \\
(55,6 \%) \\
\end{array}$ & $\begin{array}{c}232 \\
(100 \%)\end{array}$ \\
\hline
\end{tabular}


Tabel 5 juga menunjukkan distribusi untuk stunting yaitu 1 berusia 7 tahun $(0,4 \%), 28$ berusia 8 tahun $(12,1 \%), 23$ berusia 9 tahun $(9,9 \%), 29$ berusia 10 tahun $(12,5 \%), 19$ berusia 11 tahun $(8,2 \%), 2$ berusia 12 tahun $(0,9 \%)$ dan 1 berusia 13 tahun $(0,4 \%)$. Untuk anak tidak stunting didapatkan 19 berusia 7 tahun $(8,2 \%), 34 \mathrm{v}$ 8 tahun $(14,7 \%), 27$ berusia 9 tahun (11,6\%), 32 berusia 10 tahun $(13,8 \%), 12$ berusia 11 tahun $(5,2 \%), 3$ berusia 12 tahun $(1,3 \%)$, dan 2 berusia 13 tahun $(0,9 \%)$.

Tabel 6 menunjukkan jumlah anak stunting sebanyak 32 dari kelas $3(13,8 \%)$, 22 dari kelas $4(9,5 \%), 42$ dari kelas 5 $(18,1 \%)$, dan 7 dari kelas $6 \quad(3,0 \%)$ sedangkan anak tidak stunting didapatkan 51 dari kelas 3 (22\%), 28 dari kelas 4 $(12,1 \%), 38$ dari kelas $5(16,4 \%)$, dan 12 dari kelas $6(5,2 \%)$.

Pengujian perbedaan prestasi belajar antara anak stunting dengan tidak stunting menggunakan uji t tidak berpasangan yang mendapatkan nilai $\mathrm{t}=-0,788$ dengan nilai $P=0,215(\alpha=0,05)$. Hasil uji ini menyatakan tidak terdapat perbedaan rerata prestasi belajar antara anak stunting dan tidak stunting.

Tabel 6. Tabulasi silang kelas dan stunting

\begin{tabular}{cccc}
\hline Kelas & $\begin{array}{c}\text { Stunting } \\
\mathbf{n}(\%)\end{array}$ & $\begin{array}{c}\text { Tidak } \\
\text { stunting } \\
\mathbf{n}(\%)\end{array}$ & $\begin{array}{c}\text { Total } \\
\mathbf{n}(\%)\end{array}$ \\
\hline Kelas 3 & $32(13,8 \%)$ & 51 & 83 \\
Kelas 4 & 22 & $(22 \%)$ & $(35,8 \%)$ \\
& $(9,5 \%)$ & $(12,1 \%)$ & $(21,6 \%)$ \\
Kelas 5 & $42(18,1 \%)$ & 38 & 80 \\
& & $(16,4 \%)$ & $(34,5 \%)$ \\
Kelas 6 & 7 & 12 & 19 \\
& $(3,0 \%)$ & $(5,2 \%)$ & $(8,2 \%)$ \\
Total & 103 & 129 & 232 \\
& $(44,4 \%)$ & $(55,6 \%)$ & $(100 \%)$ \\
\hline
\end{tabular}

Tabel 7. Hasil uji perbedaan prestasi belajar antara anak stunting dan tidak stunting

\begin{tabular}{ccccc}
\hline Stunting & n & Rerata & $\begin{array}{c}\text { Simpangan } \\
\text { Baku }\end{array}$ & Uji t \\
\hline Stunting & 103 & 67,16 & 13,497 & \\
Tidak stunting & 129 & 68,53 & 13,044 & $P=0,215$ \\
Total & 232 & 67,92 & 13,236 & \\
\hline
\end{tabular}

\section{BAHASAN}

Penelitian ini dilakukan pada anak SDN di Kecamatan Tikala Manado berusia 7-13 tahun dengan jumlah 232 responden. Penelitian ini dilakukan sejak bulan Oktober 2018 hingga November 2018.

Responden anak stunting maupun tidak stunting pada penelitian ini didapatkan dari 5 sekolah dasar di Kecamatan Tikala. Terdapat 29 dari SDN 31, 34 dari SDN 54, 67 dari SDN 55, 66 dari SDN 91 dan 36 dari SDN 105.

Data yang diambil dalam penelitian ini ialah usia, tinggi badan, jenis kelamin, kelas, dan nilai rapor ujian tengah semester terakhir yang dilaksanakan. Dari 306 responden, terdapat 74 responden yang masuk ke dalam kriteria eksklusi karena tidak memberikan nilai rapor ujian tengah semester. Dari 232 responden anak yang didapatkan dibagi menjadi dua yaitu anak stunting dan tidak stunting yang kemudian menjadi kontrol dalam penelitian ini. Terdapat 103 anak stunting (44\%) dan 129 anak tidak stunting $(56 \%)$.

Pada penelitian ini didapatkan 117 responden $(50 \%)$ berjenis kelamin laki-laki dan 115 responden $(50 \%)$ berjenis kelamin perempuan. Terdapat 50 dari 103 anak stunting berjenis kelamin laki-laki dan 53 sisanya ialah perempuan (Tabel 5).

Kelompok usia yang dijadikan responden ialah usia anak sekolah 7-13 tahun. Usia terbanyak responden stunting ialah usia 10 tahun $(12,5 \%)$ yaitu 29 dari 103 responden. Yang paling sedikit ialah usia 7 
dan 13 tahun $(0,4 \%)$ yaitu 1 dari 103 , diikuti oleh usia 12 tahun $(0,9 \%)$ yaitu 2 dari 103 responden stunting. Demikian juga distribusi kelas pada responden stunting didapatkan lebih sedikit pada kelas 6 $(3,0 \%)$ yaitu 7 dari 103. Terbanyak pada kelas $5(18,1 \%)$ yaitu 42 dari 103 responden stunting. Namun data ini belum dapat menyatakan bahwa kejadian stunting lebih banyak terdapat pada anak perempuan, usia 10 tahun, atau pada kelas 5 dikarenakan banyak responden yang dieksklusi karena tidak memberikan nilai rapor ujian tengah semester.

Menurut Riskesdas 2013, ${ }^{3}$ prevalensi stunting secara umum laki-laki lebih tinggi dari perempuan. Prevalensi stunting pada anak usia 5-12 tahun ialah 30,7\%, dan untuk Sulawesi Utara berada sedikit di bawah dari data nasional tersebut. Pada usia 7 tahun didapatkan prevalensi stunting yaitu $26,4 \%$, usia 8 tahun yaitu $28 \%$, usia 9 tahun $30,8 \%$, usia 10 tahun $33 \%$, usia 11 tahun $35,5 \%$, usia 12 tahun $36,3 \%$, dan usia 13 tahun $37,2 \%$.

Hubungan antara stunting dengan prestasi belajar diuji dengan uji $t$ tidak berpasangan yang mendapatkan nilai $\mathrm{t}=$ 0,788 dengan nilai $P=0,215$. Hasil uji ini menyatakan tidak terdapat perbedaan rerata prestasi belajar antara responden stunting dan tidak stunting $(P=0,215>\alpha=0,05)$.

Hasil penelitian ini sejalan dengan penelitian yang dilakukan Agustin et $\mathrm{al}^{10}$ mengenai hubungan antara status gizi dengan prestasi belajar anak kelas 4 dan 5 Sekolah Dasar di Kelurahan Maasing Kecamatan Tuminting Kota Manado. Hasil analisis statistik menunjukkan tidak terdapat hubungan bermakna antara status gizi kurang dengan prestasi belajar.

Pada penelitian yang dilakukan oleh Muchlis ${ }^{11}$ mengenai hubungan status gizi dengan prestasi belajar siswa Sekolah Dasar Negeri 063 di Pesisir Sungai Siak Kecamatan Rumbai Pesisir Kota Pekanbaru berjumlah 93 siswa. Hasil uji statistik menggunakan uji chi-square menunjukkan tidak terdapat hubungan status gizi dengan prestasi belajar anak $(P=0,771)$.

Demikian pula dengan penelitian yang dilakukan oleh Nirmala et al $^{12}$ mengenai hubungan status stunting dan prestasi belajar pada siswa siswi kelas 4, 5, dan 6, di SD Negeri 1 Mawasangka Kecamatan Mawasangka Kabupaten Buton Tengah, dengan jumlah sampel 36 anak stunting dari 98 anak. Hasil uji statistik dengan menggunakan uji Mann Whitney mendapatkan nilai $P=0,694$ (tingkat kepercayaan 95\%) yang menunjukkan bahwa tidak terdapat hubungan bermakna antara status stunting dan prestasi belajar.

Prestasi belajar anak dapat dipengaruhi oleh banyak faktor baik yang bersumber dari dalam diri sendiri (faktor internal) maupun dari luar diri sendiri (faktor eksternal). ${ }^{12}$ Prestasi belajar yang baik tidak hanya dicapai dengan asupan gizi yang optimal tetapi terdapat hal-hal lain yang dapat memengaruhi prestasi belajar di antaranya, motivasi belajar siswa, konsentrasi belajar siswa, pendekatan dan perhatian orang tua terhadap anak yang dapat membentuk mental dan karakter dari anak, minat belajar anak dan lingkungan dimana anak ini tumbuh dan berkembang. ${ }^{9}$

Seorang siswa yang bersikap conserving (apatis) terhadap ilmu pengetahuan cenderung mengambil pendekatan belajar yang sederhana dan tidak mendalam. Sebaliknya, siswa yang berintelegensi tinggi dan mendapat dorongan positif dari orang tuanya, akan memilih pendekatan belajar yang lebih mementingkan kualitas hasil pembelajaran. ${ }^{14}$

Pada penelitian yang dilakukan oleh Septiani $^{14}$ didapatkan bahwa siswa dengan prestasi kurang lebih banyak pada siswa dengan ayah berpendidikan rendah $(67,3 \%)$ $(P=0,002)$. Dalam penelitian ini juga didapatkan siswa dengan prestasi kurang lebih banyak pada siswa dengan ibu berpendidikan rendah $(66,1 \%)(P=0,001){ }^{15}$

Hasil penelitian ini berbeda dengan penelitian yang dilakukan oleh Yuniarti et $\mathrm{al}^{8}$ serta Arfines dan Puspitasari ${ }^{7}$ yang melaporkan bahwa terdapat hubungan antara stunting dengan prestasi belajar. Stunting yang disebabkan oleh kekurangan gizi kronis akan menyebabkan penurunan jumlah sel dalam otak dan terjadi ketidak 
matangan serta ketidak sempurnaan organisasi biokimia dalam otak. Keadaan ini akan memengaruhi perkembangan kecerdasan anak. $^{15}$

Perbedaan hasil penelitian yang didapat mungkin dikarenakan perbedaan populasi tempat peneliti melakukan penelitian dan besarnya populasi yang diteliti.

\section{SIMPULAN}

Berdasarkan hasil penelitian yang dilakukan di SD Kecamatan Tikala Manado dapat disimpulkan bahwa tidak terdapat hubungan bermakna antara stunting dan prestasi belajar.

Ucapan terima kasih ditujukan kepada Prof. Dr. dr. Max F. J. Mantik, $\operatorname{SpA}(\mathrm{K})$, dr. Reynald O. Takumansang, $\operatorname{SpA}(\mathrm{K})$, serta semua pihak baik secara langsung maupun tidak langsung telah memberikan saran dan menumbuhkan ide dalam penulisan artikel ini.

\section{DAFTAR PUSTAKA}

1. de Mercedes O, Francesco B. Childhood stunting: a global perspective. Matern Child Nutr. 2016;12:12-26.

2. Mesfin F, Berhane Y, Worku A. Prevalence and associated factors of stunting among primary school children in Eastern Ethiopia. Dove Medical Press. 2015;7:618.

3. Badan Penelitian dan Pengembangan Kesehatan Kementrian Kesehatan RI. Riset kesehatan dasar (Riskesdas 2013). Jakarta: Kementrian Kesehatan Republik Indonesia, 2013; p. 211-8.

4. Badan Penelitian dan Pengembangan Kesehatan Kementrian Kesehatan RI. Riset kesehatan dasar provinsi Sulawesi Utara. Jakarta: Kementrian Kesehatan Republik Indonesia, 2009; p. 26-7.

5. Selasa LA, Woda RR, Davidz IKLA. Hubungan stunting dan riwayat panjang lahir dengan prestasi belajar pada siswa Sekolah Dasar Inpres Taurus 1 Nusa
Tenggara. Cendana Medical Jurnal. 2016;6:13-24

6. Ridwan. Kegiatan belajar terhadap prestasi yang dicapai. 2008. (online). Available from: http://ridwan202.wordpress. com 20080423kegiatan-belajar-danprestasi. htm, diakses 17 Agustus 2018.

7. Arfines PP, Puspitasari DF. Hubungan stunting dengan prestasi belajar anak sekolah dasar di daerah kumuh, Kotamadya Jakarta Pusat. Buletin Penelitian Kesehatan. 2017;45:45-52.

8. Yuniarti MA, Hadi H, Adiyanti MG. Status stunting dengan prestasi belajar pada siswa sekolah dasar di Kecamatan Sukodono Kabupaten Sidoarjo tahun 2012. Medica Majapahit.2014;6:59-77.

9. Idwan WI, Yusran S, Nirmala F. Hubungan status stunting dan prestasi belajar pada siswa siswi kelas 4, 5, dan 6, di SD Negeri 1 Mawasangka Kecamatan Mawasangka Kabupaten Buton Tengah Tahun 2017. JIMKESMAS. 2018;3:1-9.

10. Agustini CC, Malonda NS, Purba RB. Hubungan antara status gizi dengan prestasi belajar anak kelas 4 dan 5 sekolah dasar di Kelurahan Maasing Kecamatan Tuminting Kota Manado. Manado: Fakultas Kesehatan Masyarakat, Universitas Sam Ratulangi; 2013.

11. Muchlis. Hubungan status gizi dengan prestasi belajar siswa Sekolah Dasar Negeri 063 di Pesisir Sungai Siak Kecamatan Rumbai Pesisir Kota Pekanbaru. Jom FK. 2015;3:1-10.

12. Syah M. Psikologi belajar. Jakarta: PT. Radjagrafindo Persada, 2007; p. 144-57.

13. Santanughosh, Samburath $R$, Battacharya M. Nutritional status and learning achievement. J Res Child Educ. 2013; 29:157-62.

14. Septiani S. Hubungan status gizi (Indeks $\mathrm{TB} / \mathrm{U}$ ) dan faktor lainnya dengan prestasi belajar siswa SDN Cinere 2, Cinere Depok Tahun 2012 [Skripsi]. Depok: Fakultas Kesehatan Masyarakat; 2012.

15. Khomsan A. Ekologi Masalah Gizi, Pangan, dan Kemiskinan. Bandung: Alfabeta, 2012. 